\title{
Improved Thermally Grown Oxide Scale in Air Plasma Sprayed NiCrAlY/Nano-YSZ Coatings
}

\section{Mohammadreza Daroonparvar, Muhamad Azizi Mat Yajid, Noordin Mohd Yusof, and Mohammad Sakhawat Hussain}

Department of Materials, Manufacturing and Industrial Engineering, Faculty of Mechanical Engineering,

Universiti Teknologi Malaysia, 81310 Johor Bahru, Johor, Malaysia

Correspondence should be addressed to Mohammadreza Daroonparvar; mr.daroonparvar@yahoo.com

Received 26 December 2012; Accepted 13 February 2013

Academic Editor: Fathallah Karimzadeh

Copyright (C) 2013 Mohammadreza Daroonparvar et al. This is an open access article distributed under the Creative Commons Attribution License, which permits unrestricted use, distribution, and reproduction in any medium, provided the original work is properly cited.

\begin{abstract}
Oxidation has been considered as one of the principal disruptive factors in thermal barrier coating systems during service. So, oxidation behavior of thermal barrier coating (TBC) systems with nanostructured and microstructured YSZ coatings was investigated at $1000^{\circ} \mathrm{C}$ for $24 \mathrm{~h}, 48 \mathrm{~h}$, and $120 \mathrm{~h}$. Air plasma sprayed nano-YSZ coating exhibited a trimodal structure. Microstructural characterization also demonstrated an improved thermally grown oxide scale containing lower spinels in nanoTBC system after $120 \mathrm{~h}$ of oxidation. This phenomenon is mainly related to the unique structure of the nano-YSZ coating, which acted as a strong barrier for oxygen diffusion into the TBC system at elevated temperatures. Nearly continues but thinner $\mathrm{Al}_{2} \mathrm{O}_{3}$ layer formation at the $\mathrm{NiCrAlY/nano-YSZ}$ interface was seen, due to lower oxygen infiltration into the system. Under this condition, spinels formation and growth on the $\mathrm{Al}_{2} \mathrm{O}_{3}$ oxide scale were diminished in nano-TBC system compared to normal TBC system.
\end{abstract}

\section{Introduction}

Conventional TBC system usually consists of yttria stabilized zirconia (YSZ) as top coat (TC), an MCrAlY ( $\mathrm{M}=\mathrm{Ni}$ and/or $\mathrm{Co})$ oxidation-resistant metallic bond coat (BC) and $\mathrm{Ni}$ based superalloy as a substrate $[1,2]$. Recently, air plasma sprayed nano-YSZ coatings have shown better performance than the conventional YSZ coatings [3, 4]. In this regard, nanostructured YSZ layer showed better thermal shock resistance and lower thermal diffusivity compared to that of conventional YSZ coating [4].

Oxygen transfer through the TC towards the $\mathrm{BC}$ would occur at elevated temperatures by microcracks and interconnected pinholes inside the TC. Therefore, an oxidized scale would be formed on the $\mathrm{BC}$ which is called thermally grown oxide (TGO) layer which is mainly related to the oxidation of the BC. TGO layer also plays an important role in the failure of TBC, due to the growth of the TGO layer during oxidation $[1,2,5]$. On the other hand, the TGO thickness can be increased during oxidation process which is accompanied by evolution of stresses at the BC/YSZ interface. This stress would cause the delamination of the coating at the $\mathrm{BC} / \mathrm{YSZ}$ interface [6]. It has been reported that the stresses in TBC increase with a growing TGO layer [7]. Hence, the thicker TGO layer has larger stresses than the thinner one $[6,8]$.

Nowadays, atmospheric plasma sprayed nanozirconia coatings have been investigated by many investigators, because they provide superior properties in comparison to normal TBC (YSZ) coatings [9-11]. It can be speculated that nanostructured YSZ layer would have less pinholes and voids because of the compactness and homogeneity of the nanostructure. So, it is anticipated that nanostructured YSZ layer could considerably reduce the penetration of oxygen into the TBC system at higher temperatures.

Continues but thinner $\mathrm{Al}_{2} \mathrm{O}_{3}$ (TGO) layer formation at the $\mathrm{BC} / \mathrm{TC}$ interface of TBC system was seen by Chen et al. [5] under low oxygen pressure condition. So, in this paper, lower oxygen activity at the $\mathrm{BC} /$ nano-YSZ interface can be expected during oxidation which would help nearly continues but thinner $\mathrm{Al}_{2} \mathrm{O}_{3}$ (TGO) layer formation with slow growth in TBC system $[5,12]$. It was also found that, spinels formation on the thicker and discontinues TGO $\left(\mathrm{Al}_{2} \mathrm{O}_{3}\right)$ layer is much more in comparison to thinner and nearly continuums TGO 
TABLE 1: Used materials in this paper for production of normal and nano-TBC systems.

\begin{tabular}{lccr}
\hline Used materials & Function & Brand & Size range of powders \\
\hline Nano-YSZ powders (granulated) & As top coat & Nanox Powder S4007 (Inframat, USA) & $15-150 \mu \mathrm{m}$ \\
Normal YSZ powders & As top coat & Metco 204 NS-G & $-106+11 \mu \mathrm{m}$ \\
Normal NiCrAlY powders & As bond coat & Amdry 962 & $-106+52 \mu \mathrm{m}$ \\
Inconel & As substrate & 738 & - \\
\hline
\end{tabular}

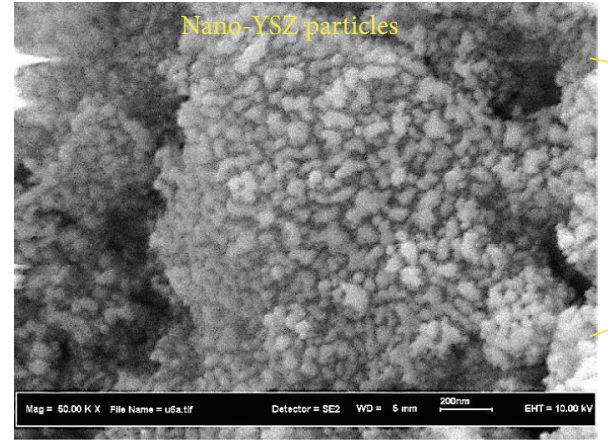

(a)

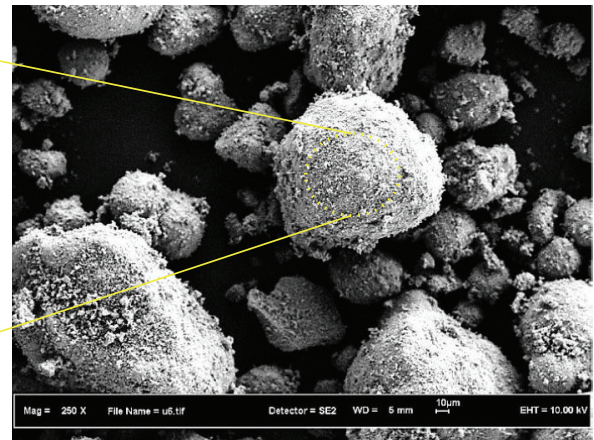

(b)

FIGURE 1: Granulated nano-YSZ powders at different magnifications: (a) 250x and (b) 50000x.

layer [12]. It means that TBC system with lower TGO thickness has better oxidation behavior compared to TBC system with thicker TGO layer.

A few researchers have studied TGO formation and growth at the BC/TC interface of nano-TBC systems during high temperature oxidation. Therefore, isothermal oxidation behavior of TBC systems with micro- and nano-YSZ coatings was explored at $1000^{\circ} \mathrm{C}$ for $24 \mathrm{~h}, 48 \mathrm{~h}$, and $120 \mathrm{~h}$. TGO growth in $\mathrm{TBC}$ systems was elaborated after oxidation at $1000^{\circ} \mathrm{C}$ for different times of oxidation.

\section{Experimental Procedures}

2.1. Used Materials and As-Sprayed TBCs. Table 1 shows used materials in this paper for production of normal and nanoTBC systems. It should be mention that the coatings were deposited through air plasma spray machine (Sulzer Metco with $3 \mathrm{MB}$ gun).

The surface of substrates (Inconel 738) was grit blasted with 24-50 mesh alumina grit and under a pressure of $0.28-0.32 \mathrm{MPa}$ before spraying the coatings. They were then preheated at $70-100^{\circ} \mathrm{C}$ and followed by the coatings were sprayed on them. The primary and the secondary plasma gases were argon and hydrogen, respectively. In this regard, optimized parameters of air plasma spray method are listed in Table 2.

2.2. Oxidation (Isothermal Oxidation) Test at $1000^{\circ} \mathrm{C}$. Samples were put in an electrical furnace with air atmosphere at $1000^{\circ} \mathrm{C}$ for $24 \mathrm{~h}, 48 \mathrm{~h}$, and $120 \mathrm{~h}$. The specimens were then furnace cooled. The sample removal before complete cooling of the furnace was prohibited to prevent thermal shocks. Also, TGO thickness was measured by image analyzer after oxidation at $1000^{\circ} \mathrm{C}$ for different times.
TABLE 2: Parameters of air plasma spraying method.

\begin{tabular}{lccc}
\hline Parameters & Normal NiCrAlY & Normal YSZ & Nano-YSZ \\
\hline Current (A) & 450 & 550 & 620 \\
Voltage (V) & 50 & 70 & 65 \\
$\begin{array}{l}\text { Primary gas, Ar } \\
\text { (L/min) }\end{array}$ & 85 & 38 & 35 \\
$\begin{array}{l}\text { Secondary gas, } \mathrm{H}_{2} \\
\text { (L/min) }\end{array}$ & 15 & 17 & 6 \\
$\begin{array}{l}\text { Powder feed rate } \\
\text { (g/min) }\end{array}$ & 15 & 35 & 30 \\
Spray distance $(\mathrm{cm})$ & 15 & 7.5 & 8 \\
\hline
\end{tabular}

2.3. Microstructural Characterization. Surface and crosssection of the coatings before and after oxidation test were characterized by using field emission scanning electron microscopy (FESEM) and scanning electron microscopy (SEM) equipped with energy dispersive spectrometer (EDS). In the meantime, in order to detect the type of formed oxide phases on the bond coat after $120 \mathrm{~h}$ of oxidation, XRD was conducted (Siemens-D500) by using $\mathrm{Cu} \mathrm{K} \alpha$ line generated at $40 \mathrm{kV}$ and $35 \mathrm{~mA}$.

\section{Results and Discussion}

3.1. Granulated Nano-YSZ Powders. As shown in Figure 1, nanoparticles can be observed in a granulated YSZ particle (Figure 1(a)). The nanoparticles must be reconstituted into micron-sized spherical granules by granulation process before air plasma spraying, because an individual nanoscale particle with low mass and high specific area does not have enough inertia required to cross the streamlines in the spray 


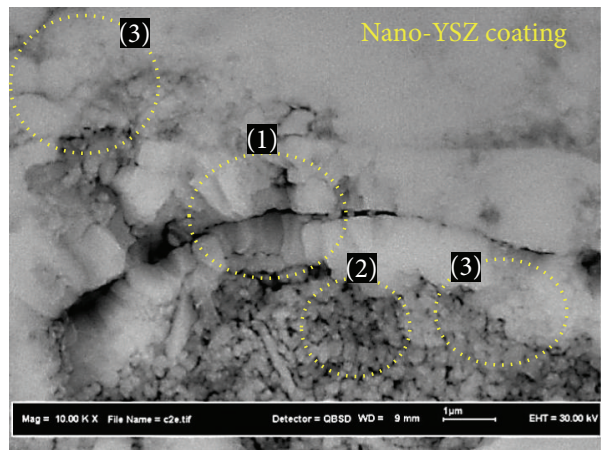

FIGURE 2: Cross-section of as-sprayed nano-YSZ coating (with a trimodel structure), (1) columnar grins, (2) semimelted nano powders, and (3) micro- and nanoequiaxed grains.

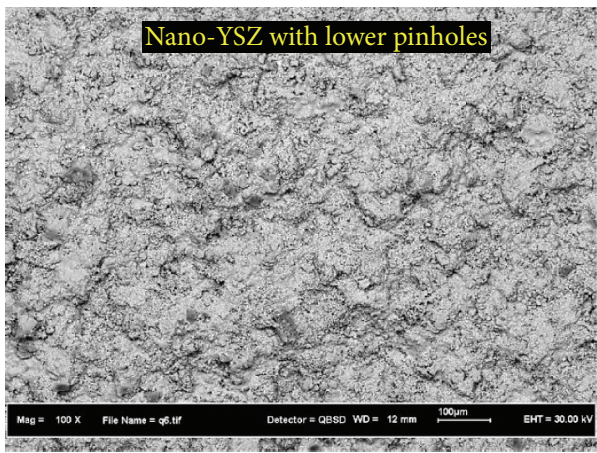

(a)

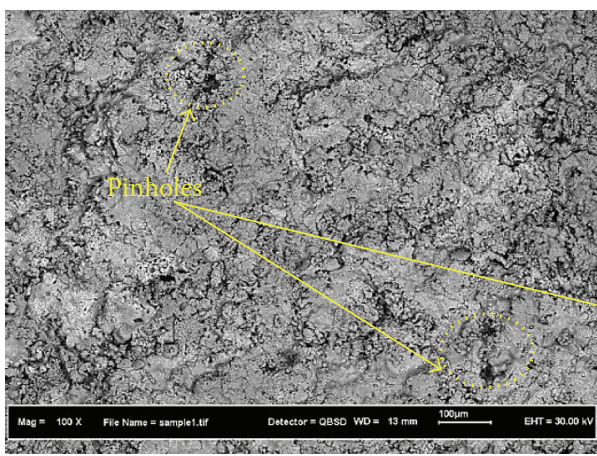

(c)

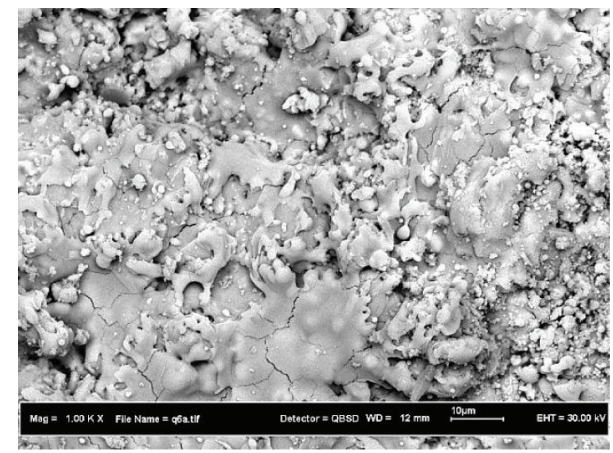

(b)

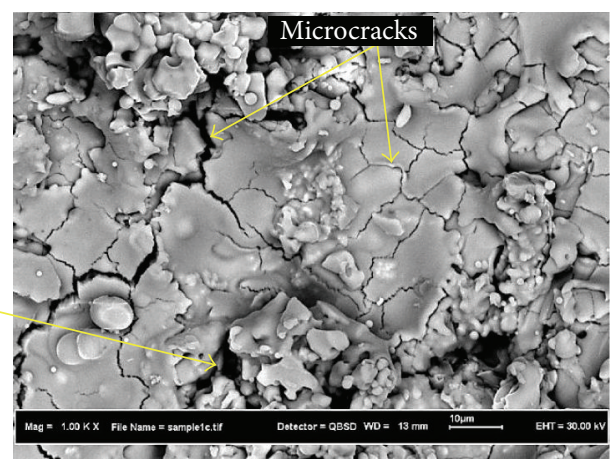

(d)

FIGURE 3: Outer surface of as-sprayed coatings: ((a) and (b)) nanostructured YSZ coating and ((c) and (d)) conventional YSZ layer.

jet $[4,11]$. The granulated nano-YSZ (air plasma sprayable) powders are approximately spherical shaped, as shown in Figure 1(b).

3.2. As-Sprayed Coatings. Figure 2 shows cross-section of assprayed nano-YSZ coating which demonstrates a trimodal distribution of the coating. This observation is in agreement with previous investigations [9-11]. This trimodal distribution consists of laminar layers with columnar grains (1) which are surrounded with semimelted parts of the nanostructured powders (2) and some equiaxed grains (3) (micro- and nanosized grains). It should be mentioned that, in order to maintain the preexisting nanostructure of the feedstock, it is essential to partially melt the powder particles during air plasma spraying [9-11] which generates a trimodal texture in the nano-YSZ coating as compared to microstructured YSZ coating. This phenomenon is mainly related to optimized parameters of air plasma spray method for spraying granulated nano-YSZ powders. In this regard, Figure 2 obviously indicates that the coating has remained nanostructured (containing nanoregions).

The existence of voids and microcracks as one of the characteristics of air plasma sprayed coatings can be observed on the outer surface of TBCs, as shown in Figure 3. It can be speculated that nanostructured YSZ coating includes less pores, voids, and microcracks (Figures 3(a) and 3(b)), because of the compactness of the nanostructure (see Figure 4). On the other hand, in the nanostructured YSZ coating, the 


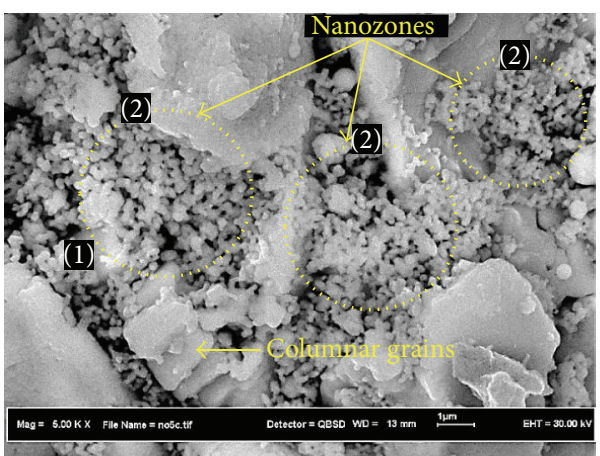

(a)

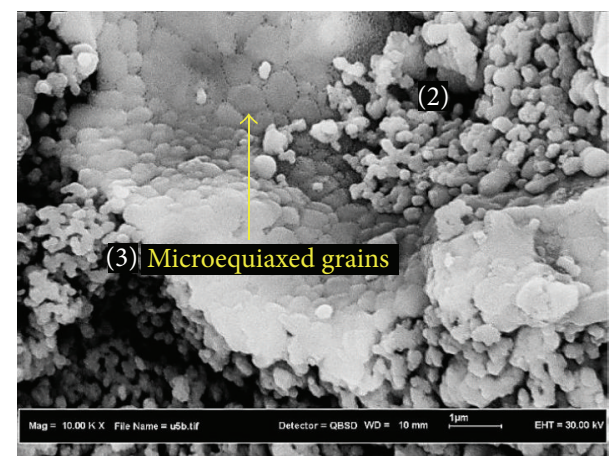

(b)

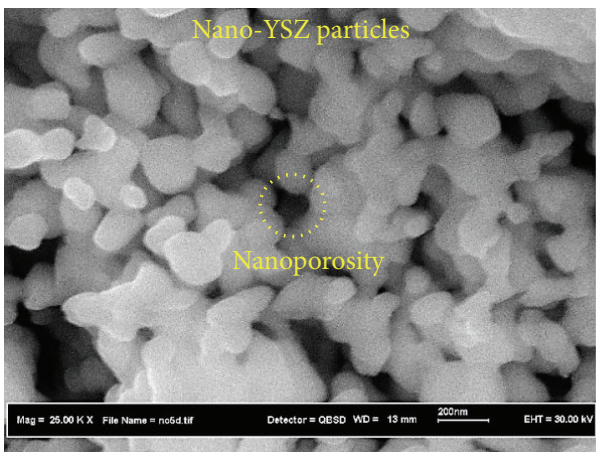

(c)

FIGURE 4: Outer surface of as-sprayed nano-YSZ coating at high magnifications: (a) 5000x, (b) 10000x, and (c) 25000x.

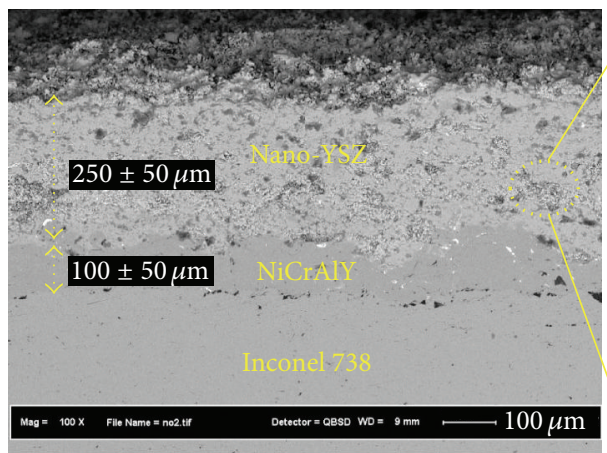

(a)

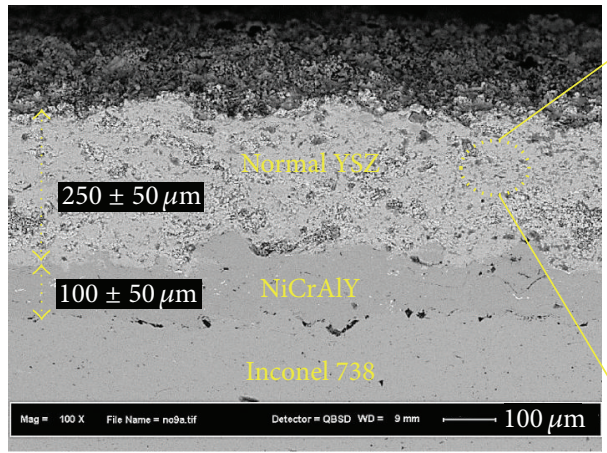

(b)

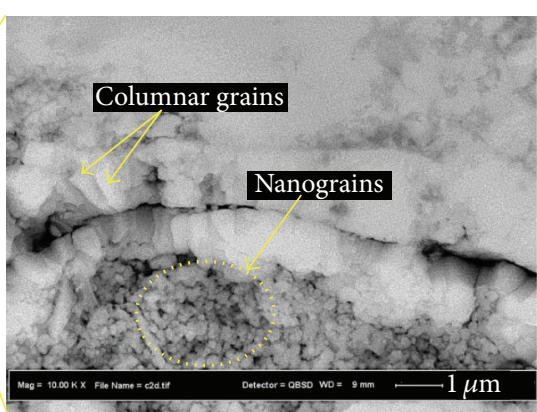

(A)

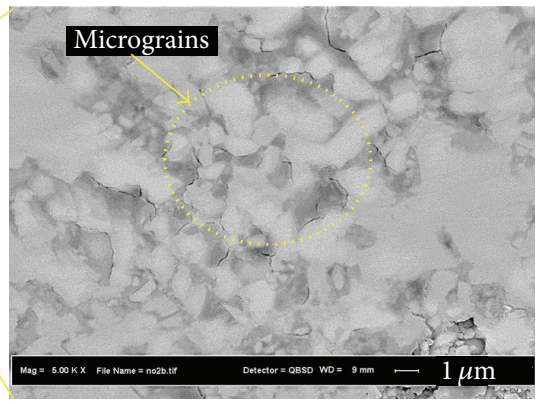

(B)

FIGURE 5: Cross-section of as-sprayed TBCs: (a) NiCrAlY/nano-YSZ coating and (b) NiCrAlY/normal YSZ coating. 


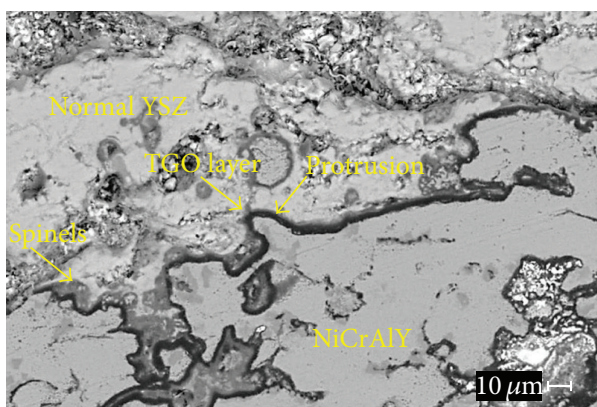

(a)

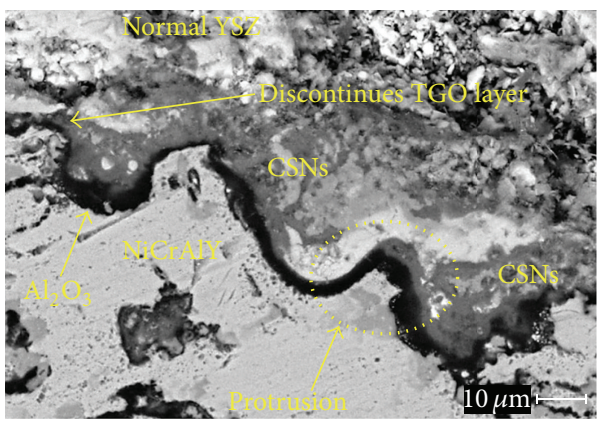

(c)

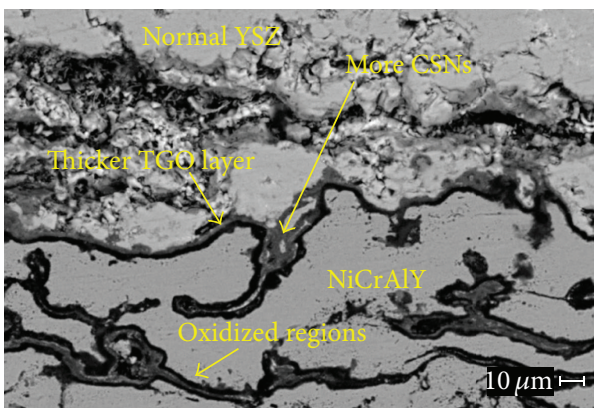

(e)

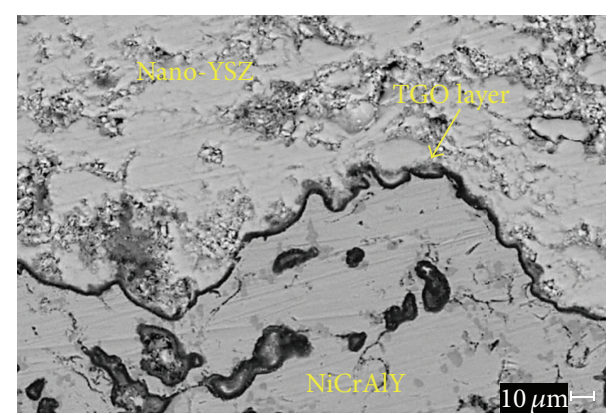

(b)

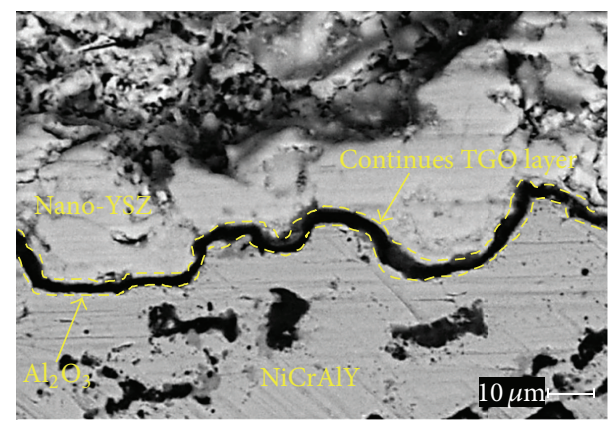

(d)

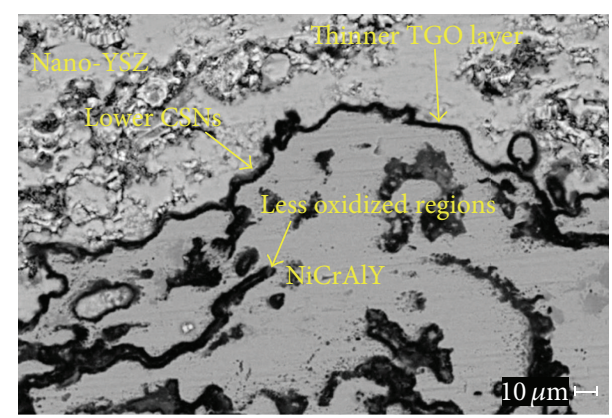

(f)

Figure 6: Cross-section of coatings after oxidation at $1000^{\circ} \mathrm{C}$ : ((a), (c), and (e)) NiCrAlY/normal YSZ coating after $24 \mathrm{~h}, 48 \mathrm{~h}$, and $120 \mathrm{~h}$ of oxidation, respectively, and ((b), (d), and (f)) NiCrAlY/nano-YSZ coating after $24 \mathrm{~h}, 48 \mathrm{~h}$, and $120 \mathrm{~h}$ of oxidation, respectively.

inhomogeneities and interconnected pores are significantly lessened. This case is presumably related to the packness of the nanostructure which may be attributed to the existence of nanozones (containing nanoporosities and nanoparticles) in the nano-YSZ coating which act as a strong barrier for oxygen infiltration into the TBC at elevated temperatures.

Less pinholes or microcracks in the YSZ layer will result in lower $\mathrm{O}_{2}$ penetration into the TC at elevated temperatures $[3,4,13]$. In contrast, much more pinholes and microcracks can be observed on the conventional YSZ coating after air plasma spraying (Figures 3(c) and 3(d)). The lower oxidation resistance of conventional YSZ is due to inhomogenously distributed microcracks and open pores (pinholes or microporosities) in the normal YSZ coating [3], which can provide the pathways for more oxygen infiltration towards the $\mathrm{BC}$ during oxidation.

Figure 5 shows the cross-section of as-sprayed TBCs. It is expected that nanostructured YSZ layer including unique structure (Figure 5(a) (A)) could act as a strong barrier for oxygen diffusion into the TBC system during thermal exposure in air compared to conventional YSZ coating containing micrograins (Figure 5(b) (B)).

3.3. Oxidation Behavior of TBCs at $1000^{\circ} \mathrm{C}$ for $24 \mathrm{~h}, 48 \mathrm{~h}$, and $120 \mathrm{~h}$. Figure 6 indicates the cross-section of the coatings after oxidation at $1000^{\circ} \mathrm{C}$ for $24 \mathrm{~h}, 48 \mathrm{~h}$, and $120 \mathrm{~h}$. It can be observed that an oxide scale (TGO) is formed at the BC/YSZ interface of all the coatings after oxidation, due to oxygen infiltration through the ceramic layer towards the BC. In the meantime, internal oxidation of the $\mathrm{BC}$ occurred during oxidation, due to oxygen infiltration through the porosities of the bond coat and microcracks of the TGO layer into the BC [12].

Formation of a somewhat continues but thinner TGO layer on the NiCrAlY layer of NiCrAlY/nano-YSZ coating can be observed after oxidation at $1000^{\circ} \mathrm{C}$ for different times, as shown in Figures 6(b), 6(d), and 6(f). But, the thickness of the TGO layer in NiCrAlY/nano-YSZ coating was lower 


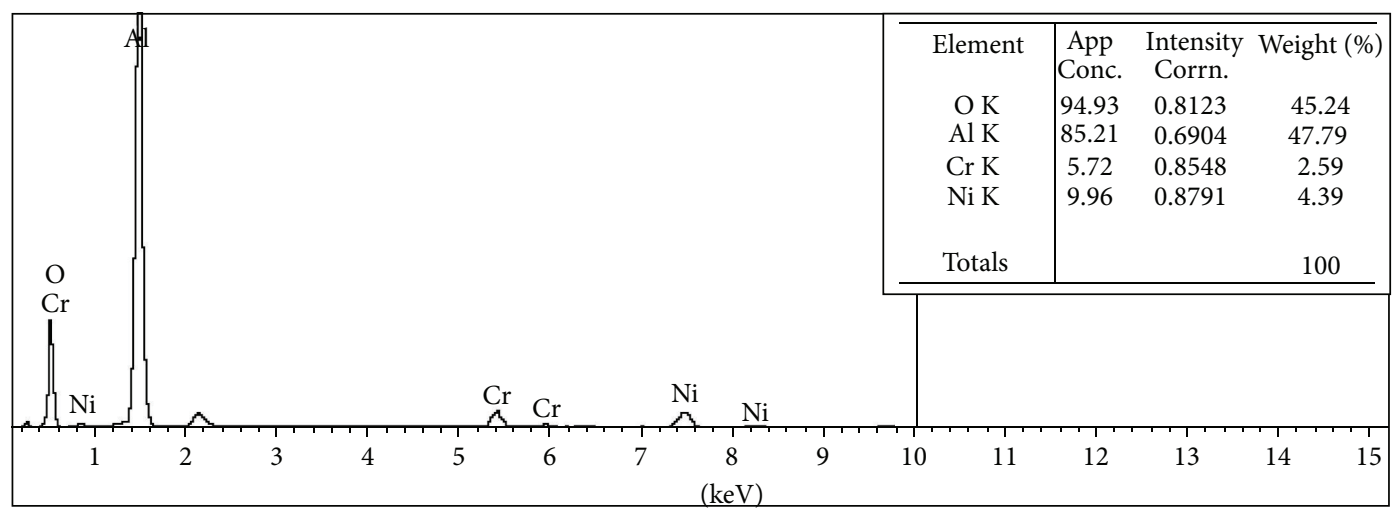

FIGURE 7: EDS analysis of the TGO $\left(\mathrm{Al}_{2} \mathrm{O}_{3}\right)$ layer.

in comparison to NiCrAlY/normal YSZ coating with thicker TGO layer (see Figures 6(a), 6(c), and 6(e)). This is because of the presence of nanostructured YSZ layer (with unique structure (Figures 2 and 4)) on the NiCrAlY layer. The lower TGO thickness in nano-TBC system may be also related to less $\mathrm{O}_{2}$ infiltration within the nanostructured YSZ coating and lower oxygen activity at the NiCrAlY/nano-YSZ interface during oxidation.

During thermal exposure in air, oxidation of the $\mathrm{BC}$ would cause TGO layer formation which is mainly composed of alumina $[12,14]$. Some oxide clusters of chromia, spinel, and nickel oxide were observed on the alumina oxide scale (as pure TGO) during extended thermal exposure in service $[15,16]$, as shown in Figures 6(c) and 6(e). The creation of more tensile stresses at the $\mathrm{BC} / \mathrm{TC}$ interface is a result of the excessive TGO growth which finally leads to the separation of the YSZ layer from the $\mathrm{BC}$ during oxidation $[15,17]$.

Monolayered TGO $\left(\mathrm{Al}_{2} \mathrm{O}_{3}\right)$ was detected by EDS analysis which showed higher percentage of oxygen and aluminum and lower percentage of nickel and chromium elements (see Figure 7).

Protrusions can be clearly observed at the TGO/YSZ interface (see Figures 6(a) and 6(c)). The summit of these protrusions is stress concentration site; hence crack nucleation and separation of the ceramic layer originate from the TGO which is formed at that interface $[2,8]$. It can be said that the thicker TGO (Figures 6(a), 6(c), and 6(e)) includes larger stresses and more spinels compared to the thinner one (Figures 6(b), 6(d), and 6(f)). In this regard, finite element analysis showed that thicker TGO layer has larger stresses in comparison with thinner TGO layer [6].

The aforementioned phenomena in the air plasma sprayed TBCs can be also elucidated by the following steps.

(1) Vertical tensile stresses at the TGO/YSZ interface and also within the YSZ layer can originate from the TGO growth.

(2) Vertical stresses on the TGO/YSZ interface would cause the propagation of horizontal microcracks inside the ceramic layer (YSZ) during oxidation.

(3) When the length of lateral microcracks reaches the length of critical crack, then separation of the YSZ

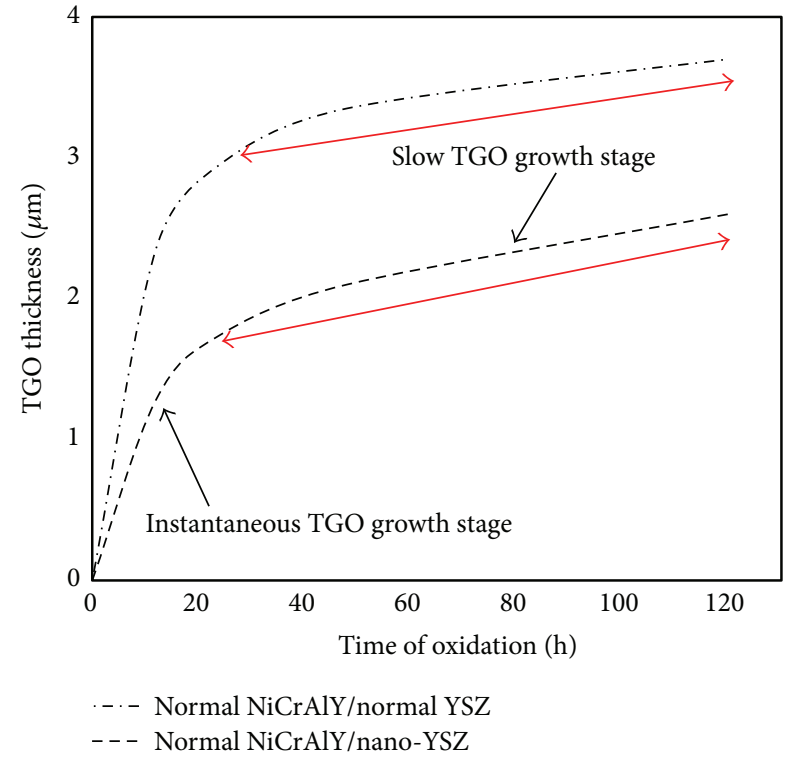

FIGURE 8: TGO thickness versus oxidation time.

layer from the $\mathrm{BC}$ will occur. NiCrAlY layer has adequate ductility; so horizontal microcracks are not able to penetrate into the $\mathrm{BC}$ at higher temperatures. In the meantime, there are many cavities at the interface of NiCrAlY/YSZ which can act as barriers for microcracks growth into the NiCrAlY layer [18].

TGO thickness was measured on each cross-sectional SEM micrograph at more than 30 different locations, and the average value was reported as TGO thickness. The variations of TGO thickness as a function of oxidation time were plotted in Figure 8.

It is clearly seen that TGO thickness has been increased with increment of oxidation time up to $120 \mathrm{~h}$ for both normal and nano-TBC systems.

In the meantime, the TGO growth rate in normal NiCrAlY/YSZ coating was higher than that of NiCrAlY/ nano-YSZ coating. Maximum growth of the TGO layer was observed in normal NiCrAlY/normal YSZ coating. But, in 

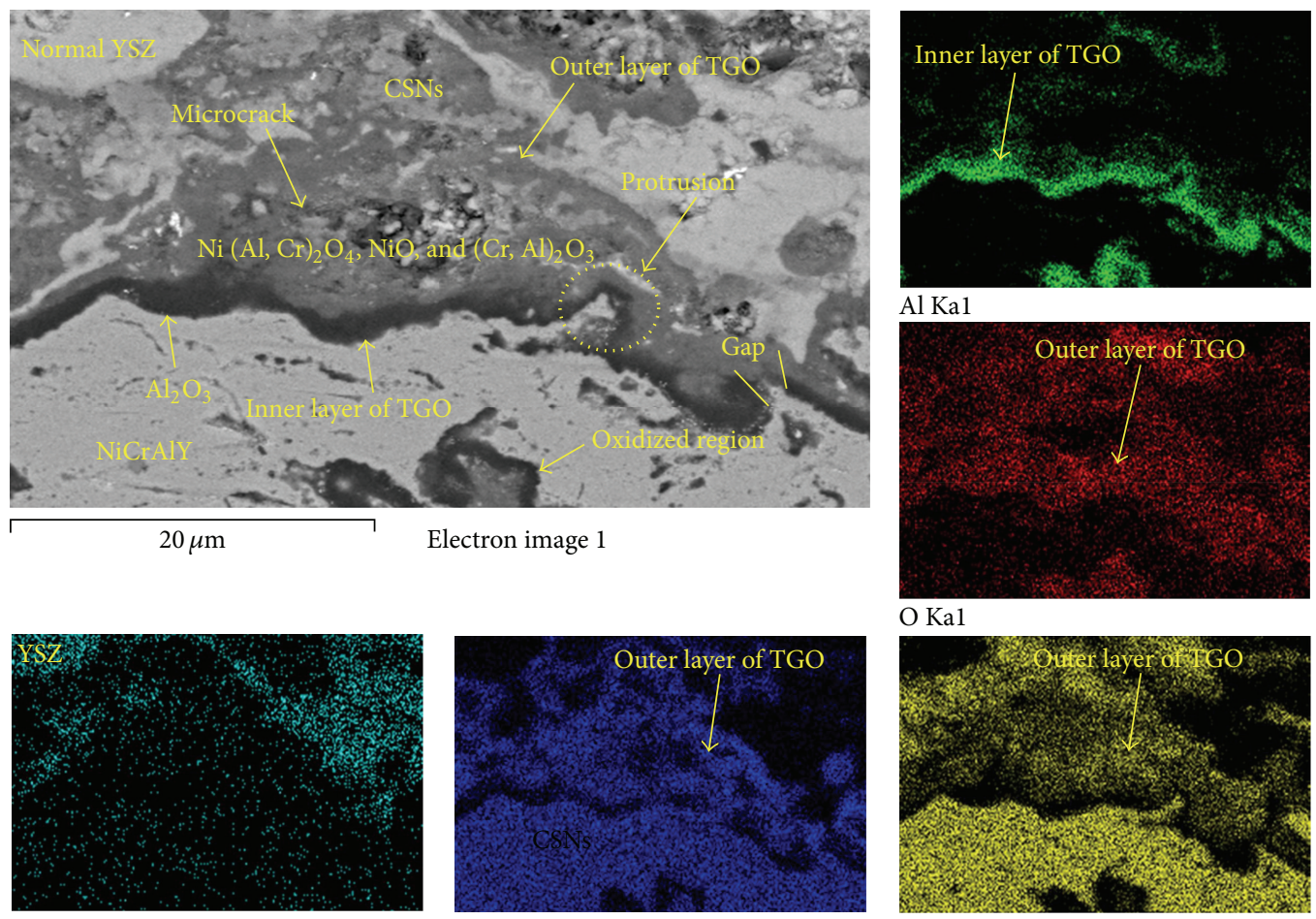

\section{Zr Kal}

Cr Ka1

Ni Ka1
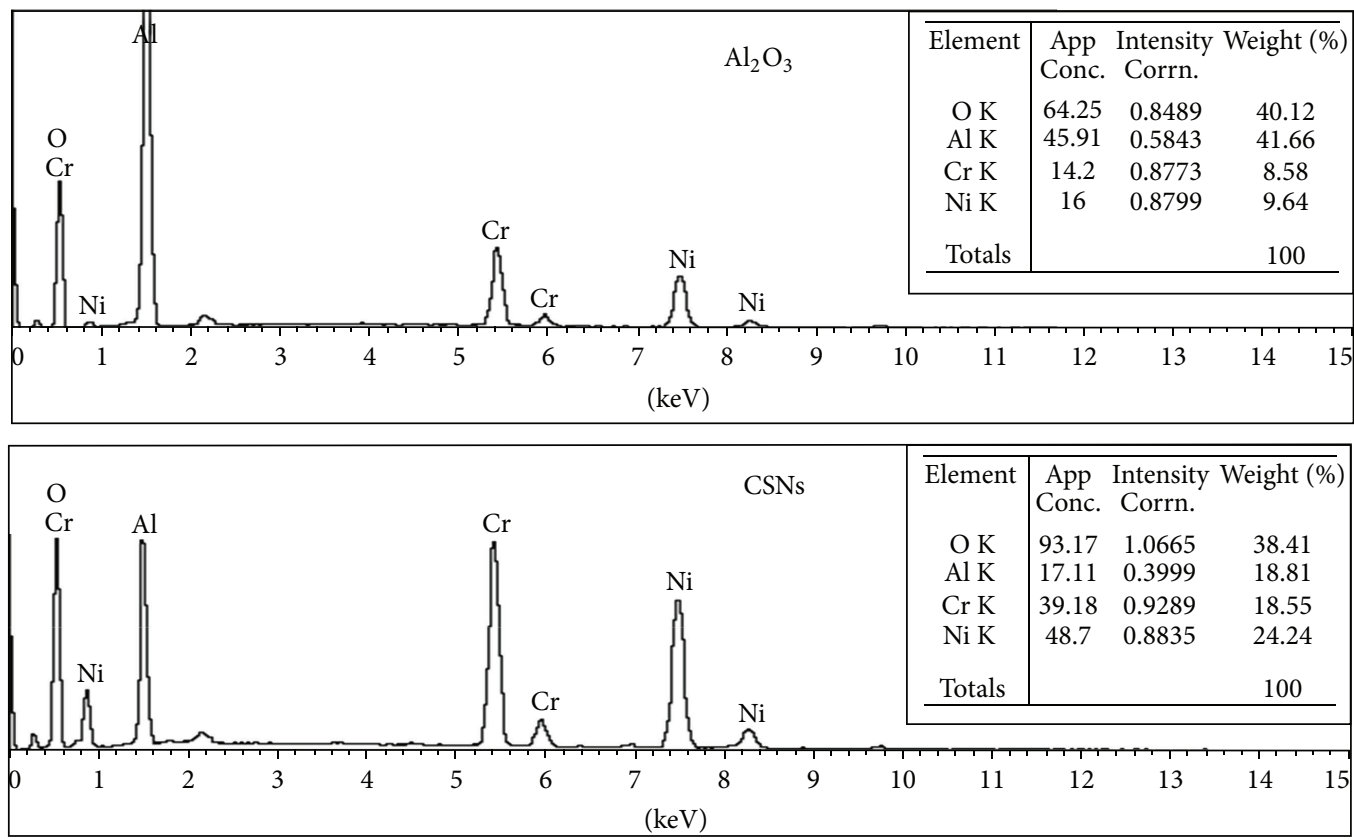

FIGURE 9: EDS analysis and X-ray map of inner and outer layers of the TGO at the NiCrAlY/normal YSZ interface after $120 \mathrm{~h}$ of oxidation.

contrast, the minimum growth of the TGO layer was seen in normal NiCrAlY/nanoYSZ coating after $120 \mathrm{~h}$ of oxidation at $1000^{\circ} \mathrm{C}$. In this regard, the TGO thickness in NiCrAlY/nanoYSZ coating was reduced to about $32 \%$ in comparison to $\mathrm{NiCrAlY/normal} \mathrm{YSZ} \mathrm{coating.}$

The TGO growth rate was very fast during the first $24 \mathrm{~h}$ of oxidation, as shown by arrow in Figure 8, and can be referred to instantaneous TGO growth. This phenomenon is mainly related to the oxygen inward diffusion and aluminum outward penetration at elevated temperatures. Slow TGO growth stage was seen after $48 \mathrm{~h}$ of oxidation, due to $\mathrm{Al}_{2} \mathrm{O}_{3}$ layer formation and growth which can influence diffusion rate and TGO growth rate during oxidation. Furthermore, parabolic manner was observed in the growth of the TGO layer which is in agreement with previous observations [12].

The chemical compositions identified by EDS and Xray map (Figure 9) of the TGO layer showed that the inner layer of TGO is composed of $\mathrm{Al}_{2} \mathrm{O}_{3}$, and the outer layer of 


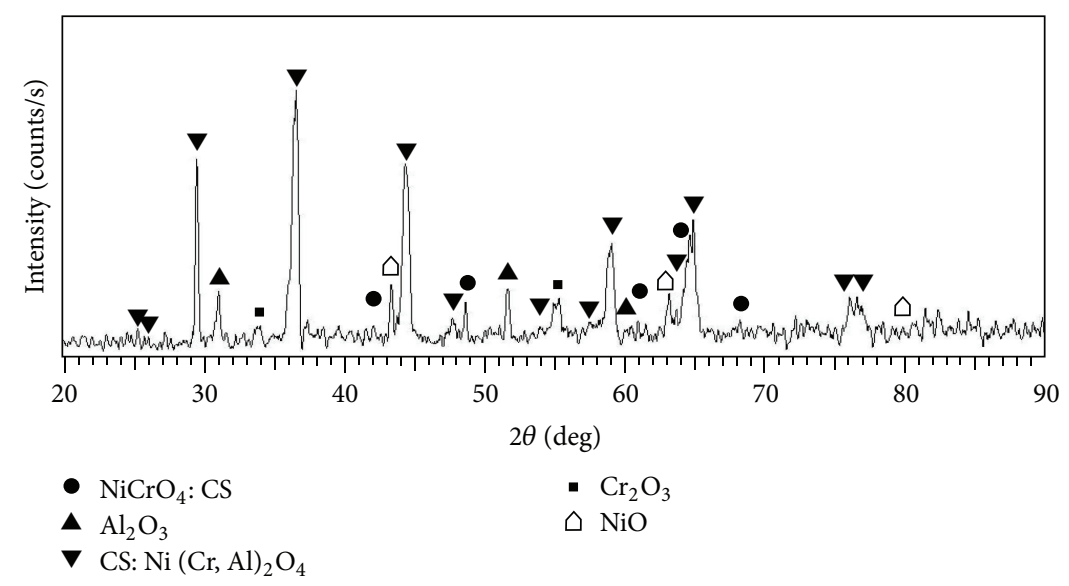

FIGURE 10: Type of formed oxide phases on the NiCrAlY layer after $120 \mathrm{~h}$ of oxidation.

TGO is mainly composed of $\mathrm{Ni}(\mathrm{Al}, \mathrm{Cr})_{2} \mathrm{O}_{4}$ (spinel or CS), $\mathrm{NiO}$, and $(\mathrm{Cr}, \mathrm{Al})_{2} \mathrm{O}_{3}$ (chromia), which are termed as CSNs $[7,12]$. This TGO layer including inner and outer layers is called bilayered TGO. The CSNs formation during high temperature oxidation was also confirmed by XRD analysis (see Figure 10). These detrimental mixed oxides (CSNs) will cause the separation of the YSZ layer from the BC during extended oxidation in air.

In this paper, the higher TGO growth rate in normal TBC system can be mainly attributed to the spinels (CSs) formed at the ceramic/bond coat interface (see Figures 6(a), 6(c), and $6(\mathrm{e}))$, since diffusion through chromia $\left((\mathrm{Cr}, \mathrm{Al})_{2} \mathrm{O}_{3}\right)$ is faster than that through $\mathrm{Al}_{2} \mathrm{O}_{3}$ (as a pure TGO layer) [19]. But, the lower TGO growth rate in nano-TBC system can be mainly related to the slow diffusion through the $\mathrm{Al}_{2} \mathrm{O}_{3}$ (TGO) before the initially formed $\mathrm{Al}_{2} \mathrm{O}_{3}$ is completely transformed to chromia + spinel (CS), which prolonged the slow TGO growth stage (start from $24 \mathrm{~h}$ ), as marked by arrow in Figure 8. This phenomenon is a direct result of the formation of a nearly continues and thinner TGO layer in NiCrAlY/nano-YSZ coating during the first $24 \mathrm{~h}$ of oxidation (see Figure 6(b)). It was found that the nanostructured YSZ layer with unique texture (particularly, the presence of semimolten nanoagglomerates in the coating structure) can considerably prevent the oxygen permeation inside the YSZ layer.

It is well known that the oxygen infiltration rate through microcracks and linked pinholes by gas penetration mechanism is higher in comparison with compacted particles (via ionic diffusion mechanism) at elevated temperatures [20]. So, the oxygen diffusion rate in nanostructured YSZ coating is lower in comparison to conventional YSZ coating with more defects (microcracks and pinholes) [21]. Lower TGO thickness and also lower CSNs formation, in nanoTBC system after $120 \mathrm{~h}$ of oxidation at $1000^{\circ} \mathrm{C}$, showed that $\mathrm{NiCrAlY/nano-YSZ} \mathrm{coating} \mathrm{has} \mathrm{better} \mathrm{oxidation} \mathrm{behavior}$ compared to NiCrAlY/normal YSZ coating with thicker TGO layer.

The somewhat continues and thinner $\mathrm{Al}_{2} \mathrm{O}_{3}$ (TGO) layer in NiCrAlY/nano-YSZ coating could also act as a diffusion barrier to diminish the formation and growth of CSNs during extended high temperature oxidation (see Figure 6(f)). This phenomenon is due to the formation of nearly continues but thinner $\mathrm{Al}_{2} \mathrm{O}_{3}$ (TGO) layer on the $\mathrm{BC}$ during the first $24 \mathrm{~h}$ of oxidation which may be related to lower oxygen activity at the $\mathrm{BC} /$ nano-YSZ interface. In other words, unique structure (especially nanozones) of the nano-YSZ coating can considerably influence the lifetime of TBC systems during service at elevated temperatures [22]. On the other hand, more CSNs formation in NiCrAlY/normal YSZ coating is due to discontinues but thicker TGO $\left(\mathrm{Al}_{2} \mathrm{O}_{3}\right)$ layer formation (see Figure 6(b)) on the bond coat in normal TBC system during oxidation. This phenomenon would significantly reduce the lifetime of normal TBC systems at elevated temperatures.

\section{Conclusions}

Formation of a nearly continues but thinner TGO $\left(\mathrm{Al}_{2} \mathrm{O}_{3}\right)$ layer at the ceramic/bond coat interface of $\mathrm{NiCrAlY} /$ nanoYSZ coating was observed during the first $24 \mathrm{~h}$ of oxidation. This thinner $\mathrm{Al}_{2} \mathrm{O}_{3}$ layer could reduce TGO growth rate which could prolong the slow TGO growth stage. In the meantime, the somewhat continues and thinner $\mathrm{Al}_{2} \mathrm{O}_{3}$ (TGO) layer in $\mathrm{NiCrAlY/nano-YSZ} \mathrm{coating} \mathrm{could} \mathrm{also} \mathrm{act} \mathrm{as}$ a diffusion barrier to suppress the formation and growth of CSNs on the alumina oxide scale during extended high temperature oxidation. This phenomenon can be mainly attributed to the presence of nanostructured YSZ coating (with nanozones) in the nano-TBC system. But in contrast, more CSNs formation in NiCrAlY/normal YSZ coating is due to discontinues but thicker TGO $\left(\mathrm{Al}_{2} \mathrm{O}_{3}\right)$ layer formation (see Figure 6(b)) on the bond coat in normal TBC system during oxidation. This phenomenon would significantly reduce the lifetime of normal TBC systems at elevated temperatures.

\section{Acknowledgment}

The authors would like to acknowledge the Ministry of Higher Education and Universiti Teknologi Malaysia (UTM) 
for providing research facilities and financial support under the Grant Q.J130000.2524.02H55.

\section{References}

[1] W. R. Chen, X. Wu, B. R. Marple, and P. C. Patnaik, "Oxidation and crack nucleation/growth in an air-plasma-sprayed thermal barrier coating with NiCrAlY bond coat," Surface \& Coatings Technology, vol. 197, no. 1, pp. 109-115, 2005.

[2] A. G. Evans, D. R. Mumm, J. W. Hutchinson, G. H. Meier, and F. S. Pettit, "Mechanisms controlling the durability of thermal barrier coatings," Progress in Materials Science, vol. 46, no. 5, pp. 505-553, 2001.

[3] M. Saremi, A. Keyvani, and M. H. Sohi, "Hot corrosion resistance and mechanical behavior of atmospheric plasma sprayed conventional and nanostructured zirconia coatings," International Journal of Modern Physics, vol. 5, no. 1, pp. 720-727, 2012.

[4] Y. Bai, Z. H. Han, H. Q. Li et al., "High performance nanostructured $\mathrm{ZrO}_{2}$ based thermal barrier coatings deposited by high efficiency supersonic plasma spraying," Applied Surface Science, vol. 257, no. 16, pp. 7210-7216, 2011.

[5] W. R. Chen, X. Wu, B. R. Marple, R. S. Lima, and P. C. Patnaik, "Pre-oxidation and TGO growth behaviour of an air-plasmasprayed thermal barrier coating," Surface \& Coatings Technology, vol. 202, no. 16, pp. 3787-3796, 2008.

[6] L. Y. Ni, C. Liu, H. Huang, and C. G. Zhou, “Thermal cycling behavior of thermal barrier coatings with HVOF NiCrAlY bond coat," Thermal Spray Technology, vol. 20, no. 5, pp. 1133-1138, 2011.

[7] W. R. Chen, X. Wu, D. Dudzinski, and P. C. Patnaik, "Modification of oxide layer in plasma-sprayed thermal barrier coatings," Surface \& Coatings Technology, vol. 200, no. 20-21, pp. 58635868, 2006.

[8] A. Rabiei and A. G. Evans, "Failure mechanisms associated with the thermally grown oxide in plasma-sprayed thermal barrier coatings," Acta Materialia, vol. 48, no. 15, pp. 3963-3976, 2000.

[9] N. Wang, C. Zhou, S. Gong, and H. Xu, "Heat treatment of nanostructured thermal barrier coating," Ceramics International, vol. 33, no. 6, pp. 1075-1081, 2007.

[10] Y. Zeng, S. W. Lee, L. Gao, and C. X. Ding, "Atmospheric plasma sprayed coatings of nanostructured zirconia," Journal of the European Ceramic Society, vol. 22, no. 3, pp. 347-351, 2002.

[11] H. Zhou, F. Li, B. He, J. Wang, and B. D. Sun, "Nanostructured yttria stabilized zirconia coatings deposited by air plasma spraying," Transactions of Nonferrous Metals Society of China, vol. 17, no. 2, pp. 389-393, 2007.

[12] M. R. Daroonparvar, M. S. Hussain, and M. M. Mat Yajid, “The role of formation of continues thermally grown oxide layer on the nanostructured NiCrAlY bond coat during thermal exposure in air," Applied Surface Science, vol. 261, pp. 287-297, 2012.

[13] Z. Chen, N. Q. Wu, J. Singh, and S. X. Mao, "Effect of $\mathrm{Al}_{2} \mathrm{O}_{3}$ overlay on hot-corrosion behavior of yttria-stabilized zirconia coating in molten sulfate-vanadate salt," Thin Solid Films, vol. 443, no. 1-2, pp. 46-52, 2003.

[14] M. S. Hussain and M. R. Daroonparvar, "Application of granulated nano $\mathrm{Al}_{2} \mathrm{O}_{3}$ powders in thermal barrier coatings at elevated temperatures," in Proceedings of the International Thermal Spray Conference (ASM International), pp. 200-205, 2012.

[15] W. R. Chen, X. Wu, B. R. Marple, and P. C. Patnaik, "The growth and influence of thermally grown oxide in a thermal barrier coating," Surface \& Coatings Technology, vol. 201, no. 3-4, pp. 1074-1079, 2006.
[16] Q. Wei, Z. Yin, and H. Li, "Oxidation control in plasma spraying NiCrCoAlY coating," Applied Surface Science, vol. 258, no. 12, pp. 5094-5099, 2012.

[17] E. A. G. Shillington and D. R. Clarke, "Spalling failure of a thermal barrier coating associated with aluminum depletion in the bond-coat," Acta Materialia, vol. 47, no. 4, pp. 1297-1305, 1999.

[18] A. Keyvani, M. Saremi, and M. H. Sohi, "Oxidation resistance of YSZ-alumina composites compared to normal YSZ TBC coatings at $1100^{\circ} \mathrm{C}$," Journal of Alloys and Compounds, vol. 509, no. 33, pp. 8370-8377, 2011.

[19] G. Y. Liang, C. Zhu, X. Y. Wu, and Y. Wu, "The formation model of Ni-Cr oxides on NiCoCrAlY-sprayed coating," Applied Surface Science, vol. 257, no. 15, pp. 6468-6473, 2011.

[20] A. C. Fox and T. W. Clyne, "Oxygen transport by gas permeation through the zirconia layer in plasma sprayed thermal barrier coatings," Surface \& Coatings Technology, vol. 184, no. 2-3, pp. 311-321, 2004.

[21] C. R. C. Lima, N. Cinca, and J. M. Guilemany, "Study of the high temperature oxidation performance of Thermal Barrier Coatings with HVOF sprayed bond coat and incorporating a PVD ceramic interlayer," Ceramics International, vol. 38, no. 8, pp. 6423-6429, 2012.

[22] H. Jamali, R. Mozafarinia, R. S. Razavi, and R. A. Pidani, "Comparison of thermal shock resistances of plasma-sprayed nanostructured and conventional yttria stabilized zirconia thermal barrier coatings," Ceramics International, vol. 38, no. 8, pp. 6705-6712, 2012. 

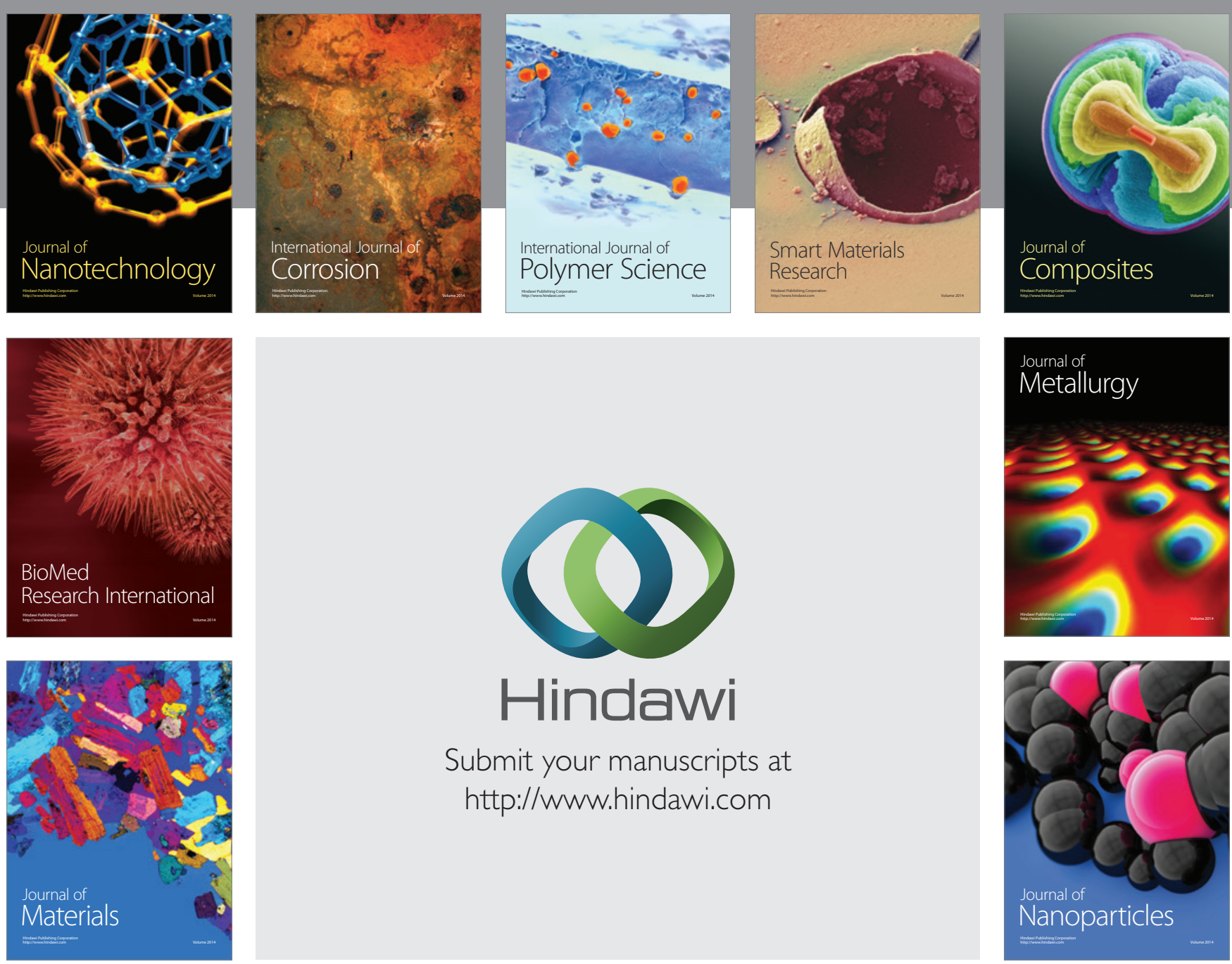

Submit your manuscripts at http://www.hindawi.com
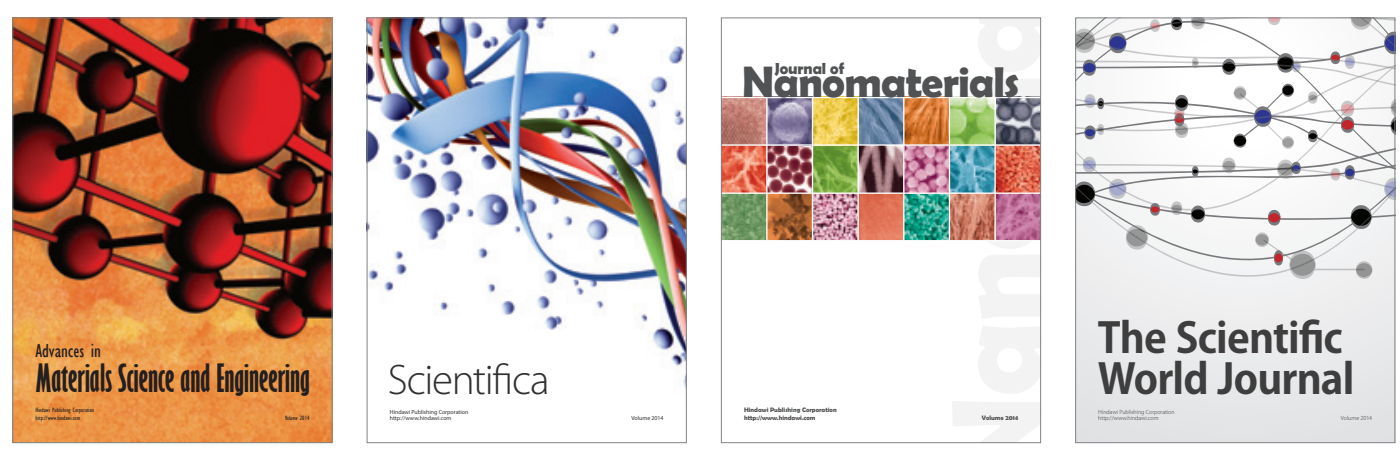

\section{The Scientific World Journal}
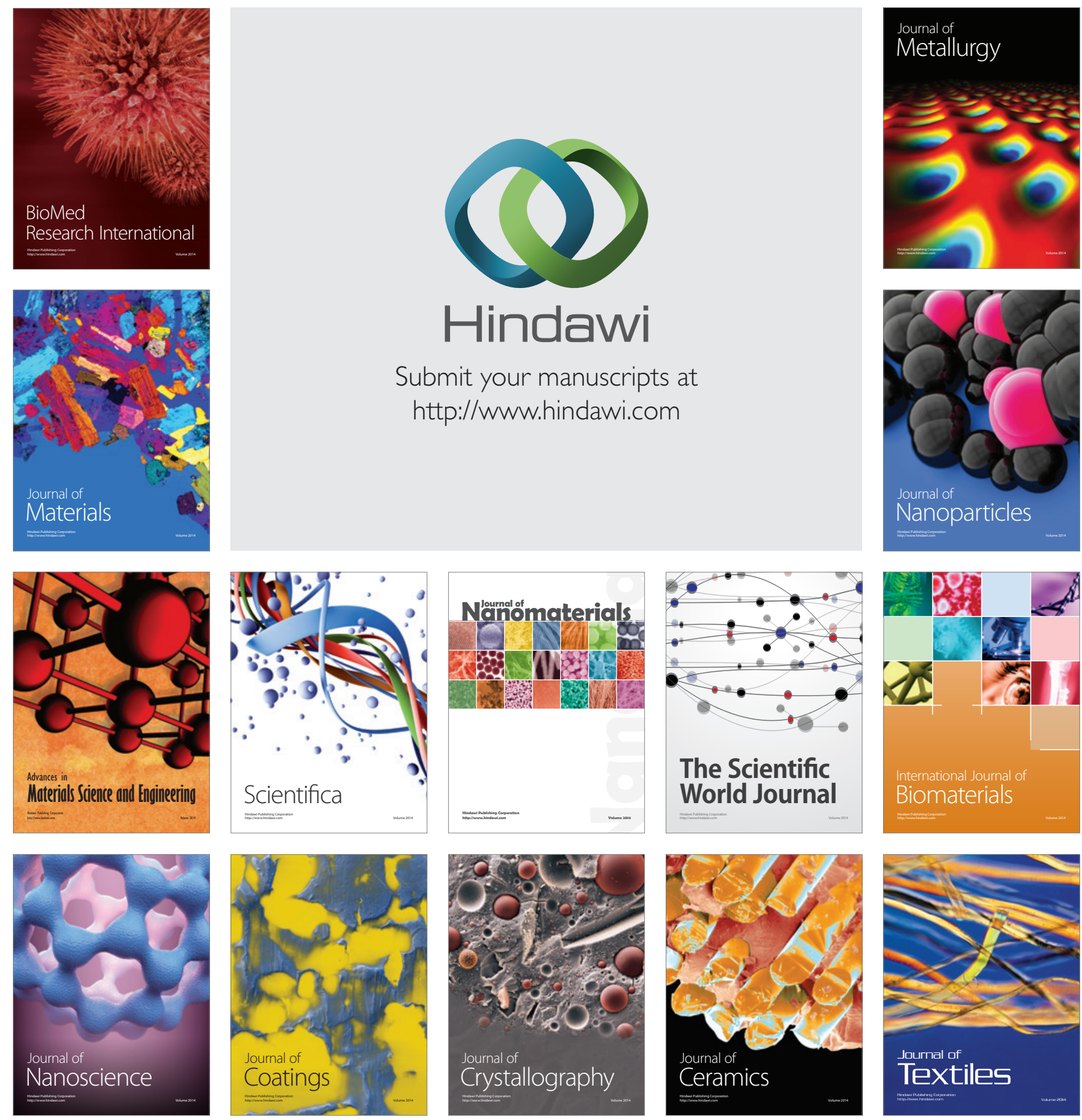